\title{
Újabb adatok Somogy megye fullánkos hártyásszárnyú (Hymenoptera: Aculeata) faunájához
}

\author{
JÓZAN ZsOLT \\ H-7453 Mernye, Rákóczi F. utca 5., Hungary \\ jozan.zsolt@citromail.hu
}

JózAn, Zs.: New data to the Aculeata (Hymenoptera) fauna of Somogy County.

Abstract: The author publishes the Aculeata species that have been found in the last two decades and are new records for Somogy county fauna. Faunistical data of the rarer species are also given. New records are for the Hungarian fauna: Priocnemis pogonoides (Pompilidae), Passaloecus borealis, Passaloecus brevilabris (Crabronidae), Nomada moeschleri (Apidae). Rare species are Elampus sanzii, Hedychridium parkanense, Hedychrum longicolle, Chrysis brevitarsis, Chrysis phryne, Chrysis sexdentata, Chrysura austriaca, Chrysura hirsuta, (Chrysididae) Cystomutilla ruficeps (Mutillidae), Arachnospila conjungens, Arachnospila opinata,Entomobora crassitarsis, Evagetes pontomoravicus (Pompilidae), Harpactus tauricus, Cerceris bupresticida, Crossocerus denticoxa, Crossocerus denticrus (Crabronidae), Nomada melathoracica (Apidae), Coelioxys acanthura (Megachilidae).

Keywords: Aculeata, rare species, faunal element, Hungary, Somogy county

\section{Bevezetés}

Somogy faunakatalógusa megjelenése óta (JózAN 2001) eltelt 17 év során folytattuk Dél-Dunántúl Aculeata faunájának kutatását. A szerző és felesége, Sasvári Mária minden évben összességében több száz gyüjtőhelyet keresett fel. Ennek eredményeképpen sok újabb faj jelenlétét mutatták ki a megyében. Ezek egy részéről több publikációban találhatók adatok (JózAN 2006a, 2007a, 2007b, 2008, 2009, 2010, 2018a). A magyarországiMutillidae- és Chrysididae fauna Muskovits József által végzett átfogó revíziója nyomána Somogy megyében gyüjtött anyagokat is átértékelhettük. A Somogy megyéből kimutatott fajok száma jelentősen gyarapodott;

A faunajegyzékből - revízió nyomán - törlendő fajok: Chrysura rufiventris, Elampus scutellaris (Chrysididae), Smicromyrme pusilla, Smicromyrme punctata (Mutillidae), Evagetes tumidosus, Priocnemis fastigiata (Pompilidae), Diodontus medius, Mimesa caucasica, Pemphredon brevipetiolatus (Crabronidae), Lasioglossum intermedium, Lasioglossum limbellum (Halictidae). A Miscophus spurius adatai a Miscophus ater fajra, a Tachysphex nitidus Tachysphex unicolor fajra vonatkoznak.

Magyarország faunájára új fajok: Priocnemis pogonoides (Pompilidae), Passaloecus borealis, Passaloecus brevilabris (Crabronidae), Nomada moeschleri (Apidae).

A bizonyító példányok túlnyomó többsége a Rippl-Rónai Múzeum (Kaposvár) gyüjteményében vannak. Néhány fajé a Magyar Természettudományi Múzeum (MTM), illetve Muskovits J. (coll. MJ) gyüjteményében található. 
1.táblázat: Az Aculeta családok aktualizált fajszáma

$\begin{array}{ll}\text { Család } & \text { fajszám } \\ \text { Chrysididae } & 110 \\ \text { Mutillidae } & 18 \\ \text { Pompilidae } & 88 \\ \text { Sapygidae } & 4 \\ \text { Scoliidae } & 5 \\ \text { Tiphiidae } & 6 \\ \text { Vespidae } & 69 \\ \text { Ampulicidae } & 2\end{array}$

\section{Család}

Crabronidae

Sphecidae

Andrenidae

Apidae

Colletidae

Halictidae

Megachilidae

Melittidae

Összesen

fajszám
224
15
114
127
46
121
101
10
$\mathbf{1 0 6 0}$

\section{Az újabb fajok listája}

\section{Chrysidoidea}

Chrysididae: Elampini

Elampus panzeri (Fabricius, 1804) - Somogytúr: Nyíres, 1973. VIII. 18. 2 hím; Szabás, temetö környéke, 2016. VII. 29. 1 nőstény 1 hím; Szenta: Baláta környéke, 1 nőstény; Kaposvár (MTM). - Melegkedvelő palearktikus elterjedési jellegü faj. Magyarországon közepesen gyakori (MóczÁR L. 1967), ám Dél-Dunántúlon kevés helyröl került elö.

Elampus sanzii (Gogorza, 1887) - Balatonboglár (MTM) - Ritka palearktikus fémdarázs fajunk. Dél-Dunántúlon a Balaton melletti lelöhelyén kívül csak Kisvaszar, Simontornya, Szekszárd és Pécs: Nagyárpád lelőhelyét ismerjük (MuskoviTs et al. manuscript).

Elampus soror (Mocsáry, 1889) - Barcs: Zátonytelep, 1999. VI. 6.3 nőstény; Mernye: Öreg-hegy, 1982. VIII. 1. 1 hím. - Magyarországon közepesen ritka, lelöhelyeinek zöme az Alföldön van (MusKoviTs et al. manuscript).

Hedychridium caputaureum Trautmann, 1909 - Balatonlelle: Jánoskert; Barcs: Drávaerdőmajor; Gamás: kisbári út; Ibafa: belterület; Kaposvár: Kisgát; Kercseliget: jágónaki út; Kereki: halastó környéke; Lábod: belterület; Látrány: Nyíres; Mernye: belterület; Mernye: Bufola; Nagybajom: Nagy-homok; Osztopán: bodrogi út; Somogygeszti: belterület; Törökkoppány: Török-kút; Zákány: Hegyalja. - Nyugat-palearktikus faj, hazánkban sokfelé előkerült, de nem gyakori (MusKoviTs et al. manuscript). MóczÁr L. (1967) a gyakori H. roseum színváltozataként tartotta számon.

Hedychridium lampadum Linsenmaier, 1959 - Balatonendréd: Karánce, 2015. VIII. 24. 2 nőstény; Balatonlelle: Kis-hegy, 2006. VIII. 24. 1 hím; Balatonszéplak (MTM); Torvaj: belterület, 2012. VII. 28. 1 nőstény. - Melegkedvelő palearktikus faj. Magyarországon Dévaványától Kőszegig találjuk lelőhelyeit, Dél-Dunántúlon ritkának bizonyult (MusKoviTs et al. manuscript). 
Hedychridium parkanense Balthasar, 1946 - Mernye: iskolaudvar, 1985. VIII. 12. 2 hím. - Nagyon ritka közép-európai faj. Ausztria, Szlovákia és Magyarország pannon területeiről ismertük (MóczÁr L. 1967). Régebbi magyarországi lelöhelyei: Paks, Siófok (MTM).

Hedychridium valesiense Linsenmaier, 1959 - Almamellék: Sasrét; Balatonszemes: Bagó-domb; Gamás: kisbári út; Kaposvár: Zaranyi lakótelep; Kaposvár: Töröcskeitónál; Lápafö: belterület; Patca: belterület; Simonfa: Hosszú-megye; Somogyszob: Kaszó; Szentbalázs: temető környéke; Töröcske: Gáj. - Ritka paleaktikus fémdarázs faj. Hazai lelőhelyeinek zöme a Dunántúlon található, de előkerült a Mátrából és a Tiszántúlról is (MusKoviTs et al. manuscript).

Hedychrum longicolle Abeille, 1877 - Kaposvár (MTM) - Ritka mediterrán faunaelem. Magyarországon kevés lelöhelyröl ismerjük (MuskoviTs et al. manuscript). Ezek többsége az Alföldön van, Dél-Dunántúlról csak a Kaposváron gyüjtött példánya származik.

Holopyga ignicollis Dahlbom, 1854 - Balatonlelle: Kis-hegy; Bánya (Bárdudvarnok): üdülőtelep; Bonnyapuszta (Bonnya); Darány: Barcsi borókás TK; Felsőmocsolád: belterület; Gamás: kisbári út; Gamás: temető; Homokszentgyörgy: belterület; Kánya: belterület; Kaposvár: Cser; Kapoly: belterület; Karád: belterület; Kereki: halastó környéke; Látrány: Látrányi P. TT; Magyaregres: belterület; Mernye: Öreg-hegy; Mezőcsokonya: temető környéke; Miklósi: belterület; Ordacsehi: temető környéke; Simonfa: Messzelátó; Siófok: belterület kelet; Somogyaszaló: belterület; Somogybabod: crosspálya; Somogysárd: belterület; Torvaj: belterület; Visz: belterület. - Gyakori mediterrán fajunk. Magyarországon sok lelöhelye ismert. Dél-Dunántúlon szintén szélesen elterjedt, de nem közönséges.

Holopyga inflammata (Förster, 1853) - Balatonboglár: Rekesz; Fonyódliget (Fonyód); Magyaregres: Gombás-erdő; Mernye: Öreg-hegy; Somogytúr: Nyíres. - Palearktikus faj, Magyarországon mérsékelten gyakori (Muskovits et al. manuscript). Ezt tapasztaltuk Somogy megye faunisztikai kutatásai során is.

Holopyga jurinei Chevrier, 1862 - Nagybajom (coll. MJ) - Mérsékelten gyakori palearktikus faj (MusKovits et al. manuscript), de Dél-Dunántúlon az itt közölten kívül csak Pécsen és Simontornyán került elö.

Pseudomalus triangulifer (Abeille, 1877) - Kereki: belterület északi részén, 2015. VI. 8. 1 nőstény - A palearktikumban elterjedt fémdarázs faj. Magyarországon ritka, csak tizenkét lelöhelyét ismerjük (Muskovits et al. manuscript). MóczÁr L. (1967) a $P$. auratus változataként sorolta be határozókulcsába.

\section{Chrysididae: Chrysidini}

Chrysis bicolor Lepeletier, 1806 - Babócsa: Dráva part; Balatonlelle: Jánoskert; Balatonszemes: Egyenes; Barcs: Zátonytelep; Bélavár: Kerék-hegy; Csököly: belterület; Csömend: belterület; Darány: Barcsi-borókás TK; Gyékényes: Lankóci-erdő; Kőkút: belterület; Homokszentgyörgy: belterület; Hosszúvíz: temető mellett; Látrány: Látrányi P. TT; Látrány: Öreg-hegy; Libickozma: belterület; Mike: belterület; Nagybajom: Homokpuszta; Nagybajom: Nagy-homok; Nemesvid: belterület; Nikla: belterület; Rinyaújnép falutól nyugatra, homokfeltárás; Somogyszob: Kanizsaberek; Somogyszob: 
Kaszó; Somogytúr: Nyíres. - Palearktikus faj, hazánkban mérsékelten gyakorinak tartjuk (MusKoviTs et al. manuscript). Somogy faunakatalógusában a besorolt Ch. succincta példányok részben a $C h$. bicolor, részben az $C h$. illigeri fajnak bizonyultak. DélDunántúl homokterületein elterjedt, de nem közönséges.

Chrysis brevitarsis Thomson, 1870 - Nagybajom: Nagy-homok, 1990. VIII. 10. 1 nőstény. - Nagyon ritka nyugat-palearktikus faj, Magyarországon az utóbbi években került elö. Az Örkényben és Pilisborosjenőn gyüjtött példányok Muskovits J. gyüjteményében vannak.

Chrysis clarinicollis Linsenmaier, 1951 - Balatonföldvár: Lucs-tető; Bélavár: Sul; Kereki: belterület északi részén; Kőkút: belterület, Lápafö: belterület; Mernye: Öreghegy; Mike: belterület; Simonfa: Bagó-hegy. - Nyugat-palearktikus faj. Hazánkban közepesen gyakori (Muskovits et al. manuscript). A Rippl-Rónai múzeum gyüjteményében található példányok eddig az Ch. ignita fajhoz voltak sorolva.

Chrysis coeruleiventris Abeille, 1878 - Balatonszemes (MTM) - Nagyon ritka, melegkedvelö észak-mediterrán elterjedésü faj. Magyarországon csak tíz lelőhelye ismert (MUSKOVITS et al. manuscript).

Chrysis comparata Lepeletier, 1806 - Zamárdi (MTM) - Ritka nyugat-palearktikus fémdarázs. Dél-Dunántúlon csak két lelöhelye ismert (MusKoviTs et al. manuscript).

Chrysis consanguinea prominea Linsenmaier, 1959 - Balatonszemes: Bagó-domb, 1989. VII. 4. 2 nőstény; Gálosfa: Dobos-hegy, 1988. VI. 4. 1 nőstény. - Közepesen gyakori nyugat-palearktikus faj. A Ch. cingulicornis fajcsoporthoz tartozik. Dél-Dunántúlon csak az itt közölt példányai kerültek elö.

Chrysis equestris Dahlbom, 1854 - Polány: belterület, 2018. VII. 31.1 nőstény. Hűvösebb élőhelyeket kedvelő nyugat-palearktikus faj. A Fauna Hungariae Chrysidoidea füzetében (MóczÁR 1967) a Ch. fasciata színváltozataként ismertették. Magyarországon ritka, tucatnyi lelőhelye Csornától Szegeden át Sátoraljaújhelyig található. DélDunántúlon ez az első előfordulása.

Chrysis frivaldszkyi Mocsáry, 1882 - Balatonlelle: Kis-hegy, 2006. VIII. 24.1 nőstény; Bárdudvarnok: Diás, 1988. VII. 31. 1 hím; Cserénfa: Fosztogatás, 1988. VII. 4. 1 hím; Darány: Barcsi borókás TK, 1983. V. 17. 2 hím, 1992. VI. 7. 1 nőstény. - Közepesen gyakori kelet-mediterrán faj (MusKovits et al. manuscript). Dél-Dunántúlon csak az itt közölt lelöhelyeken találtuk meg.

Chrysis gribodoi spilota Linsenmaier, 1951 - Vörs (MTM) - Nagyon ritka faj, melyet csak Olaszországban és Közép-Európában találtak meg (MusKoviTs et al. manuscript). Hazánkban három lelőhelyét ismerjük: Muskovits J. Dunakeszin és Törökbálinton is gyüjtötte.

Chrysis illigeri Wesmael, 1839 - Bélavár: Sul; Darány: Barcsi borókásTK; Felsőmocsolád: belterület; Heresznye: Jama; Homokszentgyörgy: belterület; Hosszúvíz: temető mellett; Kálmáncsa: településtől nyugatra, a müút mellett; Nagyberki: Kisberki; Kökút: belterület; Lábod: belterület; Marcali: Gyótapuszta; Nagybajom: farakodó; Nagybajom: Homokpuszta; Nagybajom: Lencsenpuszta; Ordacsehi: temető mellett; 
Rinyabesenyő: belterület; Somodor: belterület; Somogybabod: belterület; Somogygeszti: Bufola; Somogytúr: Nyíres; Szilvásszentmárton: belterület; Tótújfalu: Dráva völgy; Vörs: belterület. - Elterjedése a közeli rokon Ch. bicolor-hoz hasonló.

Chrysis impressa Schenck, 1856 - Felsőmocsolád: Kisbabapuszta, 2010. VI. 19. 1 hím; Mernye: Öreghegy, 1984. VIII. 16. 1 hím; Somogybabod: autócross pálya, 1988. V. 28. 1 hím; Várong: belterület, 2007. VIII. 18. 1 nőstény. - Közepesen gyakori nyugatpalearktikus fajunk (MuskoviTs et al. manuscript). Dél-Dunántúl számos pontján találtuk meg.

Chrysis iris Christ, 1791- Almamellék: Terecseny; Bonnyapuszta (Bonnya); Cserénfa: Fosztogatás; Csertő: belterület; Gálosfa: belterület; Hedrehely: belterület; Ibafa: belterület; Kaposkeresztúr: belterület; Kaposszerdahely: Tókaj, tó környéke; Mike: belterület; Polány: belterület. - A palearktikum északi részén elterjedt fémdarázs faj. Magyarországon közepesen ritka. Dél-Dunántúl tizenhat pontján gyüjtöttük.

Chrysis leptomandibularis Niehuis, 2000 - Barcs: Zátonytelep; Bonnyapuszta (Bonnya); Csököly: temető; Böhönye: Dávodpuszta; Kaposszerdahely: Tókaj, tó környéke; Marcali: Gyótapuszta; Mernye: Öreghegy; Mike: halastó környéke; Nagybajom: Homokpuszta; Osztopán: belterület; Vízvár: Dráva part. - Nyugatpalearktikus faj, Magyarországon ritka. A lelöhelyeinek többsége Dél-Dunántúlon található.

Chrysis mediadentata Linsenmaier, 1959 - Felsőmocsolád: Kisbabapuszta, 1984. VII. 25. 1 nőstény; Inke: belterület, 2007. VII. 25. 1 hím; Polány: belterület, 1984. V. 22. 1 hím; Simonfa: Messzelátó, 2012. VI. 16. 1 nőstény. - Európában elterjedt fémdarázs, Magyarországon ritka (MusKoviTs et al. manuscript).

Chrysis mediata Linsenmaier, 1951 - Gyakori palearktikus faj. Somogy megye faunakatalógusában (JózAN 2001) közölt Ch. rutiliventris adatai erre a fajra vonatkoznak. Somogy megyében az egyik leggyakoribb Chrysis faj, kilencvennél is több lelőhelyen került elö.

Chrysis phryne Abeille, 1878 -Kereki: belterület északi részén, 2017. V. 22.1 hím. Igen ritka, Közép-Európából ismert faj. Magyarországi lelőhelyeinek többsége a Budaihegység és A Balaton-felvidék területén van. Gyüjtöttük a Mecsekben is. Az Alföldön csak Kiskunfélegyházán került elö.

Chrysis schencki Linsemaier, 1968 - Babócsa: Dráva part, 1994. VIII. 5.1 nőstény; Kisasszond: belterület, 2004. VIII. 8 . 1 nőstény; Szentgáloskér: belterület, 1984. VII. 1. 1 nőstény. - A palearktikum területén elterjedt fémdarázs. Magyarországon ritka, a Dunántúl néhány pontján kívül csak a Cserhátban gyüjtötték (MusKoviTs et al. manuscript).

Chrysis sexdentata Christ, 1791 - Balatonboglár (MTM) - Ritka, palearktikus faj. Magyarországom mintegy tucatnyi lelőhelye Budapest környékén, Dél-Dunántúlon és a Balaton-felvidéken van, de elökerült a Velencei-hegységben és a Maros-Körös-közén is (Muskovits et al. manuscript). 
Chrysis solida Haupt, 1956 - Alsóbogát: belterület; Balatonszemes: Bagó-domb; Darány: Barcsi borókás TK; Gamás: kisbári útnál; Kaposvár: Toponár, Deseda; Kiskorpád: templom környéke; Látrány: Látrányi Puszta TT; Libickozma: belterület; Magyaregres: belterület; Mernye: Öreg-hegy; Mernyeszentmiklós; Ráksi: belterület; Szentbalázs: belterület. - Nyugat-palearktikus faj. Magyarországon a legtöbb lelőhelye Dél-Dunántúlon található.

Chrysis splendidula Rossi, 1790 - Balatonlelle: Kis-hegy; Fonyód: temetö; Ibafa: belterület; Látrány: Látrányi Puszta TT; Nagyberény: belterület. - Gyakori palearktikus faj, hazánkban gyakorinak tartják (MuskoviTs et al. manuscript), de Dél-Dunántúlon csak öt helyen sikerült gyüjtenünk.

Chrysis taczanovskii Radoszkowski, 1876 - Bakóca: belterület; Baranyaszentgyörgy: belterület; Csebény: belterület; Cserénfa: belterület; Drávasztára: belterület; Gige: belterület; Horváthertelend: belterület; Kaposgyarmat: belterület: Kaposkeresztúr: belterület; Kisbeszterce: belterület; Kökút: belterület; Lad: belterület; Mike: belterület; Mindszentgodisa: belterület; Mindszentgodisa: Gyümölcsény; Palé: belterület; Patca: belterület; Somogyaszaló: Antalmajor; Somogyaszaló: községi szőlő; Somogygeszti: belterület: Somogyhárságy: belterület; Somogyhatvan: belterület; Szágy: belterület; Szilvásszentmárton: belterület. - Észak-mediterrán faj. Magyarországon első példányát Vejti (Dráva mente) belterületén találtuk meg 1996-ban. Az utóbbi években egyre több helyen találtuk meg, föképpen a Zselicben (JózAN 2018a), de elökerült a Mecsekben is (JÓZAN 2018b). Lehetséges, hogy terjeszkedő (invazív) fémdarázs faj.

Chrysis terminata Dahlbom, 1854 - Széles elterjedésü palearktikus faj. LinSENMAIER (1959) nyomán az Ch. ignita fajtól különítették el. Somogy megyében gyakori, harminchét lelöhelye vált ismertté (JózAN 2018a).

Chrysura austriaca (Fabricius, 1804) - Alsóbogát: belterület, 1961. VI. 18. 1 nőstény - Palearktikus faj, hazánkban ritka. Lelőhelyei az ország számos kistáján találhatók (Muskovits et al. manuscript). Dél-Dunántúlon még egy lelőhelye ismert (Mecseknádasd).

Chrysura filiformis (Mocsáry, 1889) - Balatonszárszó: Alma-hegy, 1995. V. 6. 2 hím; Bonnya: belterület, 2009. VI. 18. 1 nőstény; Darány: Barcsi borókás TK, 1991. VI. 7. 1 hím; Gamás: Vadéi-erdö, 1993.V. 31.2 nőstény; Hajmás: belterület, 1991. VI. 30.1 hím; Somogyaszaló: Deseda, 1981. V. 30. 1 hím-Mediterrán fémdarázs faj. Magyarországon ritka, lelőhelyeinek többsége Dél-Dunántúl faunisztikai kutatása során vált ismertté.

Chrysura hirsuta (Gerstaecker, 1869) - Kaposvár (MTM) - Nyugat-palearktikus faj, Magyarországon mindössze két lelöhelyröl került elő. Régebben Keszthelyről ismertük előfordulását (MóczÁR L. 1967).

Chrysura simplex (Dahlbom, 1854) - Vörs (MTM) - Nagyon ritka mediterrán fémdarázs faj. Hazánkban csak öt lelöhelyen gyüjtötték (MusKoviTs et al. manuscript).

Pseudospinolia uniformis (Dahlbom, 1854) - Almamellék: Sasrét, 2012. VI. 16. 1 nőstény; Balatonszemes: Bagó-domb környéke, 2017. VI. 3. 1 nőstény, 2018. V. 9. 3 nöstény 3 hím, V. 23. 4 nőstény; Kereki: halastó környéke, 2018. V. 9.1 nőstény; Köröshegy: temető környéke, 2017. V. 22. 2 nőstény, 2017. VI. 3. 1 nőstény 1 hím, 2017. 
VI. 16. 1 nőstény; Szenna: lőtér, 2017. VI. 15. 1 nőstény. - Pontomediterrán faj, csak az utóbbi két évtizedben gyüjtöttük Magyarországon. Dél-Dunántúlon kívül csak Gyulán (coll. Muskovits) és a Hevesi puszták TK területén került elő (JózAN 2006b, 2018a). Lehetséges, hogy invazív faj.

\section{Vespoidea}

Mutillidae

Cystomutilla ruficeps (Smith, 1855) - Bonnya: Bonnyapuszta, 2009. VI. 30.1 nőstény. - Nagyon ritka mediterrán hangyadarázs faj. Magyarországon mindössze három lelöhelyen négy példánya - az itt közölttel együtt - került elő (MUSKOVITS \& GYÖRGY 2011).

Physetopoda daghestanica (Radoszkowski, 1885) - Boldogasszonyfa belterület; Gyékényes: kavicsbányatónál, Gyékényes: Lankóci-erdő; Fonyód (MTM); Látrány: belterület DK-i szélén; Somogyudvarhely: belterület. - Palearktikus faj, Magyarországon huszonkét lelöhelyről ismert, többségük a Dunántúlon van (MusKOviTs \& GYÖRGY 2011).

Ronisia brutia (Petagna, 1787) - Kereki: halastó környéke, 2018. V. 19. 1 nőstény, VII. 8 . 1 nőstény 2 hím. - Mediterrán hangyadarázs fajunk. Magyarországon a lelőhelyek többsége a Kiskunságon és a Dunántúli-középhegység több pontján van. Dél-Dunántúlon a Villányi-hegységben is megtaláltuk (JózAN 2000a, MusKOviTs \& GYÖRGY 2011).

Smicromyrme ruficollis (Fabricius, 1793) - Somogyacsa: Gerézdpuszta, 1988. X. 15. 1 nöstény. - Közepesen ritka mediterrán elterjedési jellegű hangyadarázs faj. Magyarországon közepesen ritka, lelőhelyeinek többsége Budapest környéki hegyvidéki- és sík területeken található (MuskoviTs \& GYÖRGY 2011). Dél-Dunántúlon gyüjtöttük még Pécsen és Pincehelyen is.

\section{Pompilidae}

Agenioideus nubecula (Costa, 1874) - Baranyaszentgyörgy: belterület, 2016. VII. 8. 1 hím; Kisasszond: belterület, 2004. VIII. 8. 1 hím. - Mediterrán területeken elterjedt útonállódarázs faj. Magyarországon a múlt század első felében csak Tihanyban és Simontornyán találták meg (MóczÁr L. 1956). A Bakony faunisztikai kutatása során elökerült a Balaton-felvidék néhány pontján (JózAN 2017). Dél-Dunántúlon gyűjtöttük még Bikács határában is.

Agenioideus usurarius (Tournier, 1889) - Edde: belterület, 2010. VIII. 5. 1 hím; Gyugy: belterület, 2010. VIII. 5. 1 nőstény; Karád: belterület, 2008. VII. 19. 1 nőstény; Libickozma: Koroknai-tó, 2005. VI. 4. 1 hím; Szőlősgyörök: belterület, 2010. VIII. 5. 1 nőstény. - Nyugat-mediterrán faj, a múlt század első felében csak Kőszegen gyüjtötték (MóczÁr L. 1956). Faunisztikai kutatásaink során megtaláltuk még Alsóörsön, Pécselyen, Simontornyán és Szabadhidvégen is.

Aporus pollux (Kohl, 1888) - Szentbalázs: temető környéke, 2010. VI. 6. 1 hím. Melegkedvelő mediterrán faj. Régebben a Kiskunság és Dunántúl homokvidékein került elő (MóczÁr L. 1956). A szerző a Villányi-hegységben (JózAN 2000a), a Mecsekben (JóZAN 2006b) és a Balaton-felvidék néhány pontján (JóZAN 2016, 2017) is megtalálta. 
Arachnospila conjungens (Kohl, 1898) - Ibafa: Gyürüfü, 2007. VI. 22. 1 nőstény. Európa néhány országában - Franciaországtól Görögországon át Belorussziáig - került elő. Magyarországon elsőként Cserkúton gyüjtöttük (JózAN 2006b). Az itt közölt a második hazai lelőhelye (JózAN 2009).

Arachnospila opinata (Tournier, 1890) - Törökkoppány: Török-kút, 2012. V. 20. 1 hím. - Észak- és Közép-Európában elterjedt útonállódarázs. Magyarországon nagyon ritka. Első példánya a Kiskunsági Nemzeti Parkban Ágasegyházán került elő (MóczÁR L. 1986), az itt közölt a második.

Ceropales pygmaea Kohl, 1880 - Balatonszemes: Egyenes, 2007. VI. 11. 1 hím; Kánya: belterület, 2009. VII. 20. 1 hím; Lápafö: belterület, 2002. VII. 14. 1 hím; Mernye: belterület, 2018. VII. 30. 1 hím; Somogyaszaló: Deseda, 2013. VII. 4. 1 nőstény. - Melegkedvelő palearktikus csempészdarázs faj. A múlt század közepéig csak simontornyai és sátoraljaújhelyi lelőhelyét közölték (MóczÁr L. 1956). Előkerült almaültetvényekben történt gyüjtések során is (JózAN 2014a).

Cryptocheilus egregius (Lepeletier, 1845) - Kereki: belterület É, 2017. V. 22. 1 hím. - Meleghez erősen ragaszkodó ritka pontomediterrán útonállódarázs. Régebben a Kiskunság több pontján, Budapest környékén, Dunaörsön, Pakson, Sukorón és Simontornyán (MóczÁr L. 1952) gyüjtötték. Dél-Dunántúl fanisztikai kutatása során elöször Pécs: Zsebe-dombon gyüjtöttük (JóZAN 2006b), később megtaláltuk Cece környékén, Pálfán és Pákozdon is.

Entomobora crassitarsis (Costa, 1887) - Szentbalázs: temető környéke (löszfeltárás), 2010. VI. 6. 1 nőstény. - Nagyon ritka mediterrán elterjedési jellegü faj. Első példánya 1955-ben a Mecsekben került elő (MóczÁR L. 1956). A fentebbi lelöhelyen kívül előkerült Tolnanémedi: Szentpéteri-hegyen is (JózAN 2014b), Tóth Sándor gyüjtötte Malaise csapdával.

Eoferreola rhombica (Christ, 1791) - Kereki: belterület északi részén, 2015. VI. 8. 1 nőstény; Látrány: Látrányi Puszta TT, 2017. V. 22. 1 hím. - Melegkedvelő pontomediterrán faj, melyet a legtöbb nagytájunkon gyüjtöttek (MóczÁr L. 1952), de mindenütt ritka. A Bakony faunisztikai kutatása során a Balaton-felvidék néhány pontján és Fenyőfőnél találtuk meg.

Evagetes pontomoravicus (Sustera, 1938) - Siófok: Töreki, 2010. VII. 5.1 nőstény. - Ritka pontomediterrán útonállódarázs faj. Közép-Európában csak Szlovákiában, Magyarországon és Csehországban gyüjtötték (Wolf 1971). A Fauna Hungariae (MóczÁr L. 1956) fajai közt nem szerepel.

Evagetes proximus (Dahlbom, 1843) - Balatonlelle: Kis-hegy, 1991. VII. 30. 1 hím. - Nyugat-palearktikus faj, inkább a hüvösebb élőhelyeket kedveli. A múlt évszázad első feléből csak Pestszentimre és Simontornya lelőhelyét közölték (MóczÁr L. 1956). Később előkerült a Kiskunsági NP három pontján (Móczár 1986). Az utóbb évtizedekben megtaláltuk a Mecsek egy pontján (JóZAN 2006b) és Tihanyban (JóZAN 2017).

Priocnemis pogonoides Costa, 1883 - Szentbalázs: temető környéke (löszfeltárás), 2017. VII. 26. 1 nőstény. - Olaszország északi részén és Délkelet-Európában kimutatott ritka faj. Előkerült Inotán (Várpalota) is. Magyarország faunájára új. 


\section{Scoliidae}

Scolia galbula (Pallas, 1771) - Buzsák: Csisztapuszta; Csököly: temető; Darány: Barcsi borókás TK; Homokszentgyörgy: belterület D-i részén; Kereki: belterület É-i részén; Kisasszond: belterület; Kőkút: településtől délre; Kőkút: Gyöngyöspuszta; Mike: belterület; Nagybajom: Homokpuszta; Nagybajom: Nagy-homok; Nikla: Takácshegy; Somogyszob: Kaszó; Szulimán: településtől nyugatra. - Palearktikus tőrösdarázs faj. Európa déli területein és Közép-Európa melegebb klímájú részein elterjedt. A Fauna Europaea Magyarországot is megjelöli az elterjedési adatai között. BAJÁRI (1956) határozókulcsában ez a faj nem szerepel. A S. hirta leírásában szereplő - „Ritkán egy-egy nöstény feje vagy egy-egy hím elötora sárgás rajzolatú." - mondat a $S$. galbula fajra vonatkozik. Morfológiai bélyeget nem közöl, ám a két faj biztos elkülönítéséhez ezek is szükségesek. A Rippl-Rónai Múzeum $S$. hirta példányainak revíziója során is számos $S$. galbula fajt találtunk, Somogy megyén kívül a Kiskunság több pontjáról, Paksról és Németkérről származó példányokat is találtunk. Valamennyi lelöhelye homokterületeken van. Ezek száma alapján mérsékelten gyakorinak bizonyul.

\section{Vespidae}

Antepipona deflenda (Saunders, 1853) - Balatonszemes: Bagó-domb; Kisdobsza: településtől Ny-ra; Szatina: belterület; Szenna: lőtér; Szentbalázs: temető környéke; Tamási: belterület keleti részén. - Mediterrán redősszárnyú darázs. MóczÁr L. (1995) szerint „Hazánkban az egyik leggyakoribb kürtősdarázs ...”. Dél-Dunántúli gyüjtéseink során csak kilenc helyen gyüjtöttük, míg az A. orbitalis száznál is több helyröl került elö. Számos más kürtősdarázs fajt is jóval több helyen találtuk meg az említett területen.

Eumenes sareptanus insolatus Mueller, 1923 - Homokszentgyörgy: belterület, 2004. VIII. 9. 1 hím; Kadarkút (D): halastó környéke; 2009. VIII. 17. 1 nőstény. - Melegkedvelö mediterrán gömböcdarázs faj. Hazánkban a ritkább fajok közé sorolható. A Dunántúlon kevesebb lelöhelyről került elő, mint az Alföldön (MóczÁr L. 1995). Faunisztikai kutatásaink évtizedei alatt Dél-Dunántúlon csak e két helyen találtuk meg. Tóth S. Malaise csapdával megfogta Tolnanémedi: Szentpéteri-hegyen (JózAN 2014b). Gyüjtöttük még Gyenesdiáson, Hajmáskéren, Paks: Ürge-mezőn és Érd környékén.

\section{Apoidea \\ Crabronidae \\ Bembicinae}

Harpactus tauricus (Radoszkowski, 1884) - Szenna: lötér környéke, 2018. VII. 5. 1 nőstény. - Nagyon ritka pontomediterrán kaparódarázs faj. Közép-Európában Szlovákiában van elterjedésének északi határa (Fauna Europaea). Magyarországon régebben csak Balatonfüreden, Simontornyán és Sukorón gyüjtötték (BAJÁRI 1957).

Nysson roubali Zavadil, 1937 - Kereki: belterület északi részén, 2016. VI. 16. 1 hím; Kereki: halastónál,2016. VI. 16. 1 hím; Kőkút: belterület keleti részén, 2017. VI. 19. 1 hím.-Nagyon ritka kaparódarázs faj, melyet eddig csak Közép-Európában (Magyarország, Szlovákia) és a Balkánon (Macedónia, Bulgária) találtak meg (Fauna Europaea). Régebben csak Simontornyán került elő (BAJÁRI 1957). Dél-Dunántúl és a Bakonyvidék faunisztikai kutatása során megtaláltuk A Balaton-felvidék két pontján illetve Pécsváradon és gyüjtöttük Bugacpusztán is (JózAN 2000b). 


\section{Crabroninae}

Crossocerus denticoxa (Bischoff, 1932) - Darány: Barcsi borókás TK, 1982. VIII. 5. 1 hím (leg. Wéber M.). - Nagyon ritka közép-európai elterjedésü szitásdarázs. Magyarországon első előfordulásait Bátorligetről, Csévharaszról, a Béda-Karapancsa Tk-ból és Barcsi-borókásból közöltük (JózAN 1990). Somogy megye faunakatalógusában nem szerepeltettük.

Crossocerus denticrus Herrich-Schaeffer, 1841 - Ibafa: Gyürüfü, 2006. V. 27. 1 nőstény. - Nagyon ritka palearktikus faj. Az 1970-es éveket megelőzően csak Kalocsán és a Tapolca-patak mentén gyüjtötték (BENEDEK 1970, MóczÁr L. 1959). Később előkerült a Bátorligeti TT-ben (JóZAN 1990).

Miscophus niger Dahlbom, 1844 - Somogyaszaló: Antalmajor, 2017. VIII. 23. 1 nőstény. - Európában szélesen elterjedt kaparódarázs faj. Magyarországon nagyon ritka, első előfordulását Velencéből közöltük (JózAN 2008). A fenti lelöhelyen kívül megtaláltuk még Velemben és Fülöpszálláson is.

Trypoxylon medium Beaumont, 1945 - Balatonföldvár: Lucs-tető; Balatonlelle: Kishegy; Böhönye: Mernyei-erdő; Csököly: temető környéke; Darány: Barcsi borókás TK; Gálosfa: Dobos-hegy; Hosszúvíz: temető környéke; Kaposgyarmat: belterület; Kaposhomok: belterület; Kaposmérö: belterület; Kaposvár: Toponár, Deseda; Karád: belterület; Kisbárapáti: belterület; Lipótfa: Ótelek; Nagybajom: Homokpuszta; Nagyberki: Kisberki; Nyim: régi temető környéke; Polány: belterület; Somogybabod: crosspálya; Szentbalázs: temető környéke; Tab: Gyári-hegy. - A Trypoxylon figulus alfajaként is - a következő fajjal együtt - nyilvántartott taxon (BOHART \& MENKE 1976). Dél-Dunántúlon sokfelé elökerült, de nem közönséges. Feltételezhető hogy a Magyar Természettudományi Múzeum gyüjteményében $T$. figulus fajként determináltak között számos példánya található.

Trypoxylon minus Beaumont, 1945 - Bárdudvarnok: belterület; Boldogasszonyfa: belterület; Büssü: temető környéke; Simonfa: Bagó-hegy; Töröcske: Gáj; Zselickisfalud: Fehér-hegy. - Az előző fajnál ritkább, Dél-Dunántúlon csak kilenc lelőhelyen találtuk meg, de gyüjtöttük a Bakony és a Mecsek több pontján is. Az előzőnél írt megállapításunk erre a fajra is vonatkozik.

\section{Pemphredoninae}

Passaloecus borealis Dahlbom, 1844 - Szentbalázs: temető környéke: 2016. IX. 3. 1 nőstény. - Európa nagy részén elterjedt faj, melyet Skandináviától Görögországig találtak meg. A Magyar Természettudományi Múzeum gyüjteményében csak a Kárpátok két, egymástól távol eső pontján gyüjtött példányok vannak (BAJÁRI 1957). Magyarország faunájára új.

Passaloecus brevilabris Merisuo, 1937 - Gamás: kisbári út mellett, 2013. IX. 5. 1 nőstény; Somogybabod: belterület, 2016. VI. 6. 1 hím. - Elterjedése az előző fajhoz hasonló. Ausztriában megtalálták (DoLlfuss 1973). A Kárpát-medencében még nem közölték előfordulását. Magyarország faunájára új.

Psenulus chevrieri (Tournier, 1889) (= brevitarsis Merisuo 1937) - Alsóbogát: belterület; Alsótapazd (Kökút): belterület; Buzsák: belterület; Drávasztára: belterület; Fonyódliget (Fonyód): belterület; Gödrekeresztúr: belterület; Inke: belterület; Kaposkeresztúr: belterület; Kisbeszterce: belterület; Lábod: belterület K; Lajoskomárom: 
belterület; Libickozma: belterület; Mernye: községi legelö; Polány: belterület; Simonfa: belterület; Somogyaszaló: belterület; Somogyaszaló: Deseda; Somogygeszti: belterület; Somogyszentpál: belterület; Somogyszob: Kaszó: Somogyvár: vasútállomás környéke; Szágy: belterület; Szenna: Gályi-árok; Szólád: belterület; Vásárosbéc: belterület. Európában sokfelé előkerült. BAJÁri (1957) nem ismertette a hazai Psenulus fajok között. Magyarország öt nagytáján gyüjtöttük (JózAN 2011). Legtöbb lelöhelye DélDunántúlon található.

Psenulus meridionalis Beaumont, 1937 - Balatonboglár: Bugaszeg; Balatonboglár: Bagó-domb; Inke: belterület; Kaposvár: Cser; Kereki: belterület északi részén; Látrány: Látrányi Puszta TT; Mernye: belterület; Mernyeszentmiklós; Nagybajom: Nagy-homok; Szentlászló: Zöcsketelep. - Mediterrán elterjedési jellegü faj. BAJÁRI (1957) a P. pallipes változataként foglalta a Psenulus határozókulcsba. Dél-Dunántúlon tíz lelőhelyen találtuk meg.

Spilomena beata Blüthgen, 1953 - Bedegkér: belterület; Csököly: temető környéke; Gadács: belterület; Homokszentgyörgy: belterület; Hosszúvíz: belterület; Inke: belterület; Kaposhomok: belterület; Kaposvár: Cseri dűlö; Kaposvár: Toponár; Kisbárapáti: belterület; Kisbeszterce: belterület; Lipótfa: Ótelek: Marcali: Gyótapuszta; Mernye: belterület; Miklósi: belterület; Mozsgó: belterület; Patca: belterület; Simonfa: belterület; Somogyaszaló: belterület; Somogyaszaló: Antalmajor; Somogybabod: Tardpuszta; Somogyhárságy: belterület; Somogytúr: belterület; Szenna: Dennai erdő; Szenna: északi löszfeltárás; Szulok: belterület; Törökkoppány: belterület; Visz: belterület; Zimány: belterület. - A faj európai és magyarországi elterjedését már részletesen ismertettük (JózAN 2008).

\section{Philanthinae}

Cerceris bupresticida Dufour, 1841 - Darány: Barcsi borókás TK, 2015. VI. 26. 1 nőstény. - Melegkedvelő mediterrán csomósdarázs faj. Magyarországon első példányát Balatonalmádiban fogták (BENEDEK 1979). A fentebb közölt a második hazai lelöhelye (JózAN 2015)

\section{Sphecidae}

Sceliphron caementarium (Drury, 1773) - Kaposvár: Cser, Cseri-patak völgye, 2018. VII. 17. 1 hím; Mernye: belterület, 2018. VI. 10. 1 hím (észlelés). - Invazív lopódarázs faj. Európában már megjelent Franciaországban, Olaszországban, Ausztriában, Horvátországban és Ukrajnában (Fauna Europaea). Magyarországon első példányait Kovács-Hortyánszki Anikó és Muskovits József gyüjtötte (VAS és JózAN 2014). Megtaláltuk Szigetmonostor környékén a 2018. évi biodiverzitási nap alkalmából is.

\section{Apidae}

Nomada goodeniana (Kirby, 1802) - Észak- és Közép-Európában elterjedt nomádméh. A Somogy faunakatalógusában szereplő $N$. succincta példányok revíziója során különítettük el ezt a fajt. Somogy dombvidékein nagyon gyakori, nyolcvan helyen gyüjtöttük.

Nomada melathoracica Imhoff, 1834 - Szenna: lőtér, 2017. VII. 7. 1 hím. - Ritka észak-mediterrán faj. Magyarországon a múlt évszázad közepéig csak Kőszegen, Örszentmiklóson (Örbottyán), Szécsényben és Bátorligeten gyüjtötték (MóczÁR \& SchWARZ 1968). Papp J. Balatonhenyén találta meg. 
Nomada moeschleri Alfken, 1913 - Bőszénfa: 2013. IV. 26. 1 nőstény. - ÉszakEurópában és Közép-Európa nyugati részén elterjedt faj. Gyüjtötték Ausztriában és Szlovéniában is (Fauna Europaea). Magyarország faunájára új.

Thyreus affinis (Morawitz, 1873) - Balatonendréd: Karánce, 2015. VIII. 24.1 nőstény; Balatonszemes: Bagó-domb környéke, 2014. VII. 17. 1 nőstény. - Ritka palearktikus foltosméh faj. Hazánkban régebben csak öt lelöhelyröl közölték előfordulását (MóczÁR M. 1958b). Dél-Dunántúlon a több évtizedes faunisztikai kutatásunk során csak a fenti két helyen gyüjtöttük.

\section{Colletidae}

Hylaeus gredleri Förster, 1871 - Nyugat palearktikus álarcosméh. A két következő fajjal együtt a $H$. brevicornis fajcsoporthoz tartozik. Somogy faunakatalógusában (JózAN 2011) nem szerepeltettük önállóként. A Somogyi-dombságon gyakori, mintegy negyven lelőhelyen gyüjtöttük.

Hylaeus imparilis Förster, 1871 - Böszénfa: belterület; Ordacsehi: belterület. Melegkedvelő mediterrán faj. Somogyban kevés lelöhelyen találtuk meg. Feltételezhetően több helyen is elökerülhet.

Hylaeus kahri Förster, 1871 - Darány: Barcsi borókás TK; Gödrekeresztúr: Felsőgödre; Szulok: belterület. - Mediterrán álarcosméh faj. Dél-Dunántúl hét pontján gyüjtöttük. A meleg-száraz élőhelyeken számíthatunk további előfordulására.

Hylaeus punctus Förster, 1871 - Barcs: Középrigóc, 2017. VII. 17. 1 nőstény. - Északmediterrán faj. Magyarországon régebben kilenc helyen találták meg, többségük az Alföldön van (MóczÁr M. 1961). Dél-Dunántúlon a fentebbi az első előfordulása.

\section{Halictidae}

Sphecodes marginatus Hagens, 1872 - Almáskeresztúr: belterület; Balatonszemes: Egyenes; Látrány: Látrányi Puszta TT. - Európában elterjedt faj. Egyes szerzők a $S$. miniatus változatának tartják (WARNCKE 1986). MóczÁR M. (1967) magyarországi előfordulást valószínüsítette. Dél-Dunántúlon csak hím példányok kerültek elő.

\section{Megachilidae}

Coelioxys acanthura (Illiger, 1806) - Szentbalázs: temető környéke, 2015. VIII. 3. 1 nőstény (leg. Sasvári M.), 2018. VII. 10. 1 nőstény. - Nagyon ritka mediterrán kakukkméh faj. A Magyar Természettudományi Múzeum gyüjteményében csak nagyon régi példányai vannak Budapestről és Fiuméból (MóczÁr M. 1958a). A fajt Magyarországról kipusztultként tartottuk nyilván (JózAN 2011). Egy löszparton találtuk meg a gazdaállat (Megachile albisecta) fészkeinek közelében.

\section{Melittidae}

Dasypoda morawitzi Radchenko, 2016 - Balatonberény: fürdőtelep; Csokonyavisonta: belterület; Darány: Barcsi borókás TK; Dombóvár: Dombóvár-alsó vasútállomásnál; Hosszúvíz: temető környéke; Kaposvár: Kisgát; Kereki: belterület; Kőröshegy: Öreghegy; Látrány: Öreghegy; Lengyeltóti: Kék-tó: Mernye: Öreghegy; Mike: belterület; Nikla: belterület; Ötvöskónyi: belterület; Polány: belterület; Rinyaszentkirály: belterület; Somodor: belterület; Somogybabod: belterület; Somogyszob: Kanizsaberek; Somogytúr: Nyíres; Somogyudvarhely: belterület; Varászló: belterület; Zamárdi: Kö-hegy. - Ezt a gatyásméh fajt 2016-ban írták le (RADCHENKo 2016). Az auctor számos lelőhelyét 
közölte Ukrajnából, Dél-Oroszországból és egyet Törökországból. Közép-Európában Németországból (Mallnow: Brandenburg) és Ausztriából (Illmitz: Burgenland), valamint Bulgáriából ismertették előfordulását (SCHMID-EGGER \& DUBITZKY 2017). Magyarországi előfordulásáról elsőként M. Shebl számolt be Vácrátóton gyüjtött példányok alapján (SHebl in print). Móczér M. (1960) a Dasypoda hirtipes változataként feltüntette a var. minor Mor. taxont, annyit írva, hogy kisebb a törzsalaknál és a Duna-Tisza közén került elö. A Rippl-Rónai Múzeum Dasypoda anyagát átvizsgálva a faj számos példányát találtuk meg sok lelöhelyröl. Ezeket eddig $D$. minor -ként determináltuk. A fent ismertetett lelőhelyeken kívül megtaláltuk a Kiskunságban, a Mecsekben, a Villányi-hegységben és a Bakonyban is.

\section{Irodalom}

BAJÁRI E. 1956: Tőrösdarázs alkatúak - Scolioidea. - in: Magyarország Állatvilága (Fauna Hungariae) XIII/3:1-35.

BAJÁRI E. 1957: Kaparódarázs alkatúak I. - Sphecoidea I. - in: Magyarország Állatvilága (Fauna Hungariae) XIII/7: 1-117.

Benedek P. 1970: Adatok a Tapolca-patak és környéke rovarfaunájához, IV. Kaparódarazsak (Sphecoidea). (Data to the insect fauna of the Tapoca Brook and its surroundings, IV. Sphecoidea). - Folia Entomologica Hungarica 23: 93-112.

Bohart, R. M. \& Menke, A. S. 1976: Sphecid Wasps of the World. - University of California Press, Los Angeles 1-695.

Dollfuss, H. 1983: Fam. Sphecidae. - In: Catalogus Faunae Austriae, ein systematisches Verzeichnis aller auf österreichischen Gebiet festgestellten Tierarten 16/1: 1-32.

JózAN, Zs. 1990: The Scolioidea, Sphecoidea and Apoidea Fauna of the Bátorliget Nature Reserves (Hymenoptera, Aculeata). - In Mahunka, S. (ed.): The Bátorliget Nature Reserves. - after forty years. Természettudományi Múzeum Budapest pp. 601-621.

JózAN Zs. 2000a: A Villányi-hegység fullánkos hártyásszárnyú (Hymenoptera, Aculeata) faunája. - Dunántúli Dolgozatok Természettudományi Sorozat 10: 267-283.

JózAN Zs. 2000b: Újabb adatok a Bakony kaparódarázs faunájának (Hymenoptera, Sphecoidea) ismeretéhez. - Folia Musei Historico-Naturalis Bakonyiensis 15(1996): 101-124.

JózAN Zs. 2001: Somogy megye fullánkos hártyásszárnyú (Hymenoptera, Aculeata) faunája. - Natura Somogyiensis 1: 269-293.

JózAN Zs. 2006a: Adatok Dél-Dunántúl fullánkos hártyásszárnyú (Hymenoptera, Aculeata) faunájának ismeretéhez. - Natura Somogyiensis 9: 279-288.

JózAN Zs. 2006b: A Mecsek fullánkos hártyásszárnyú faunája (Hymenoptera, Acueata). - Folia Comloensis 15: 219-238.

JóZAN Zs. 2007a: Újabb adatok a Zselic fullánkos hártyásszárnyú (Hymenoptera, Aculeata) faunájának ismeretéhez - Somogyi Múzeumok Közleményei B - Természettudomány 17 (2006): 169-182

JózAN Zs. 2007b: Adatok Dunántúl redősszárnyú-darázs (Hymenoptera: Vespidae) faunájának ismeretéhez. Natura Somogyiensis 10: 195-199.

JózAN Zs. 2008: Új kaparódarázs fajok (Hymenoptera, Sphecidae) Magyarország faunájában - Somogyi Múzeumok Közleményei 18: 81-83.

JózAN Zs. 2009: A biodiverzitási napon Gyürüfün gyüjtött fullánkos hártyásszárnyú (Hymenoptera: Aculeata) fajok ismertetése. - Natura Somogyiensis 13: 151-154.

JózAN Zs. 2010: Újabb fullánkos hártyásszárnyú (Hymenoptera, Aculeata) fajok Somogyból. - Natura Somogyiensis 17: 251-256.

JózAN, Zs. 2011: Checklist of Hungarian Sphecidae and Apidae species (Hymenoptera, Sphecidae and Apidae). - Natura Somogyiensis 19: 177-200.

JózAN, Zs. 2014a: Magyarországi almaültetvények ritkább fullánkos hártyásszárnyúi (Hymenoptera: Apocrita). - Natura Somogyiensis 24: 149-156.

JózAn Zs. 2014b: Adatok Simontornya fullánkos (Hymenoptera, Aculeata) faunájához - in: Simontornya ízeltlábúi - in memoriam Pillich Ferenc - ed.: Magyar Biodiverzitás-kutató társaság pp. 117-129. 
JózAN Zs. 2015: A Barcsi borókás fullánkos faunája, III. (Hymenoptera: Aculeata). - Natura Somogyiensis 26: 95-108.

JózAN Zs. 2016: A balatonfüredi Tamás-hegy fullánkos hártyásszárnyú (Hymenoptera, Aculeata) faunája. Natura Somogyiensis 30: 47-70.

JózAN Zs. 2017: A Tihanyi Tájvédelmi Körzet fullánkos hártyásszárnyú (Hymenoptera, Aculeata) faunája II. - Folia Musei Historico-Naturalis Bakonyiensis 34: 99-130.

JózAN Zs. 2018a: A Dél-Dunántúl fémdarázs faunája (Hymenoptera: Chrysididae). - Natura Somogyiensis 31: 89-106.

JózAN Zs. 2018b: Adatok a Mecsek fullánkos hártyásszárnyú (Hymenoptera: Aculeata) faunájához. - Natura Somogyiensis 31: 107-112.

LisenMayer, W. 1959a: Revision der Familie Chrysididae (Hymenoptera). - Mitteillungen der Schweizerischen Entomologischen Gesellschaft, Lausanne, 32(1): 1-232.

MóczÁr L.1952: Útonállódarazsak (Hym., Pompilidae). - Folia Entomologica Hungarica 5: 73-107.

MóczÁr L. 1956: Pókölődarázs alkatúk - Pompiloidea. - In: Magyarország Állatvilága (Fauna Hungariae) $\mathrm{XIII} / 5: 1-76$.

MóczÁr L. 1959: Kaparódarázs alkatúak II. - Sphecoidea II. - in: Magyarország Állatvilága (Fauna Hungariae) XIII/8: 1-87.

MóczÁr L. 1967: Fémdarázsalkatúak - Chrysidoidea - In: Magyarország Állatvilága (Fauna Hungariae) XIII/2: 1-118.

MóczÁr, L. 1986: The survey of the Chrysidoidea Pompiloidea and Vespoidea Fauna of the Kiskunság National Park (Hymenoptera). - In: Mahunka, S. (ed.): The Fauna of the Kiskunság National Park. I., Akadémiai Kiadó Budapest: 383-400.

MóczÁr L. 1995: Redősszárnyúdarázs szerüek - Vespoidea. - In: Magyarország Állatvilága (Fauna Hungariae) $\mathrm{XIII} / \mathrm{B} / 6: 1-181$

MóczÁr, L. \& Schwarz, M. 1968: A Nomada-, Ammobates-, Pasites- és Parammobatodes nemek faunakatalógusa (Cat. Hym. XXIII.). - Folia Entomologica Hungarica XXI/23: 339-360.

MóczÁr M. 1958a: Múvészméhek - Megachilidae - in: Magyaroszág Állatvilága (Fauna Hungariae) XIII/12: $1-78$.

MóczÁr M. 1958b: A bundásméhek (Anthophora Latr.) és fészekélősködőik, a gyász- és foltosméhek (Melecta Latr., Crocisa Latr.) revíziója, faunakatalógusa és etológiai adatai. - Folia Entomologica Hungarica XI/24: 403-421.

MóczÁr M. 1960: Ösméhek - Földi méhek, Colletidae - Melittidae. - in: Magyarország Állatvilága (Fauna Hungariae) XIII/9: 1-64.

MóczÁr M. 1961: A Kárpátmedence ősméheinek - Colletidae - revíziója, faunakatalógusa és ethológiai adatai I., Álarcosméhek - Prosopis F. (Cat. Hym. XVIII.). - Folia Entomologica Hungarica XIV/8: 143- 162.

Móczár M. 1967: Karcsúméhek - Halictidae. - in: Magyarország Állatvilága (Fauna Hungariae) XIII/11: $1-116$.

Muskovits J. \& GYöRGY Z. 2011: Magyarország hangyadarazsai - Velvet ants of Hungary. - Natura Somogyiensis 18: 1-198.

Muskovits J., Rahmé N. \& Szöke V.: Magyarország fémdarazsai (Hymenoptera, Chrysididae) pp. 1-215. (kézirat)

RADCHENKO, V. 2016: A new widespread European bee species of the genus Dasypoda Latreille (Hymenoptera: Apoidea). - Zootaxa 4189(3): 491-504.

Schmid-Egger, C. \& Dubitzky, A. 2017: Dasypoda morawitzi (Radchenko, 2016) neu für die Fauna Mitteleuropa (Hymenoptera, Apoidea). - Ampulex 9/2017: 27-31.

SHEBL, M. A. E.: Dasypoda morawitzi Radchenko 2016, a new recorded solitary bee species in Hungary (Apoidea: Melittidae) - Acta Zoologica Academiae Scientiarum Hungariae (in print)

Wolf, H. 1971: Prodromus der Hymenopteren der Tscheshosolowakei, Pars 10: Pompiloidea. - Acta Faunistica Entomologica Musei Nationalis Pragae pp. 1-76.

VAS Z. \& JózAN Zs. 2014: Újabb adatok és határozókulcs Magyarország lopódarázs faunájához (Hymenoptera: Sphecidae). - Natura Somogyiensis 24: 157-164.

WARNCKE, K. 1986: Die Wildbienen Mitteleuropas, ihre gültigen Namen und ihre Verbreitung (Insecta: Hymenoptera). - Entomofauna, supplement 3: 1-128.

FAUNA EuropaEA: all european animal species online - https://fauna_eu.org/cdm_dataportal/taxon - accessed on 17.10.2018 